\title{
Analysis of the Impact of Sustainability Education Carried Out by Qatar to Improve Its Image as a Future World Education Goal
}

\author{
Muhammad Adi Sukma Nalendra ${ }^{1}$ \\ ${ }^{1}$ Institut Teknologi Batam, Indonesia
}

\begin{abstract}
This article seeks to explain the role of the presence of various world-class educational institutions in Qatar, which is a concrete step for Qatar in the development of social and cultural. Qatar believes that education is a major way and has a strong influence to increase Qatar's inclusiveness in the world so that it can maintain a good investment climate. This research is a conceptual paper where the data presented in this study comes from literature studies from Emerald, Science Direct, and Google Scholar, where 314 articles were found which were selected and narrowed down to find 18 articles that were most suitable from the title, abstract, to useful results. This paper also conducted a simple SWOT analysis in order to map the strategy and provide a valid explanation in this study. From the results of the agreement in this paper, it can be found that as a socio-economic effort which is a long-term plan, education is not the only step that is achieved but also utilizes mass media and various other aspects.
\end{abstract}

Keywords: Education, Sustainable, Social-Culture, Inclusive, Qatar

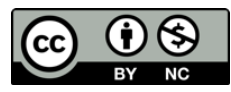

This is an open access article under the CC-BY-NC license

\section{INTRODUCTION}

Qatar is an Emirati country located in the Middle East with an area of about $11,586 \mathrm{~km}^{2}$. Qatar is a Middle Eastern country with a population of 2,363,569. Qatar is dominated by resources, namely oil and gas. According to data from the Organization of the Petroleum Exporting Countries (OPEC, 2017) Annual Statistical Bulletin in 2017, Qatar's oil production is 651,500 barrels per day, with oil reserves reaching 25,244 billion barrels. Apart from oil, Qatar's economic development is inseparable from the production and export of Liquid Natural Gas (LNG), which is Qatar's largest source of income to date. In terms of politics, Qatar is a small country dominated by the largest Persian Gulf ruling family, namely Al Thani, with the head of state is the Amir (James, 2009). Qatar and the other Gulf States are members of an international organization, namely the Gulf Cooperation Council (GCC, 2014). The GCC is a political and economic alliance of six countries in the Persian Gulf, namely Bahrain, Kuwait, Oman, Qatar, Saudi Arabia and the United Arab Emirates. It was established in 1981 with the aim of having coordination, integration and interconnection between the Member States in all fields. The achievement of the GCC is the formation of economic and political integration. GCC Economic Integration contained in article 4 of the GCC Charter refers specifically to the need for cooperation among member countries in economic affairs, finance, trade, customs, transportation and others, while the achievements of the GCC in the political field are the 
establishment of joint actions and security cooperation, including joint defense agreements, defense integration, comprehensive security strategies and several cooperations in combating drug attacks, as well as cooperation against nuclear and radioactive risks. But in 2017, the diplomatic severance by the Gulf countries had supported Iran and the ties that occurred in Qatar, so that the severance of relations had an impact on the Qatari economy (Mohanty, 2018).

From the above explanation above, we could provide problems that will be conducted in this research consist of: first, the measure taken by Qatar to improve their national education system in order to achieve future educational destination programme (Ramthall, 2000); the second is the strategic steps of Qatar's future educational destination program (Scherp, 2013), and the third is the solution to solving the problems of Qatar's future educational destination as a persuasive perspective since unacceptable for several countries (García-González., et al. 2000). Fourth, lessons learned from sustainable education strategy, which is soft power from the state of Qatar. Furthermore, this study also tries to analyze this phenomenon by using the SWOT analysis technique (strengths, weaknesses, opportunities and threats) in the implementation of Qatar's soft diplomacy on the complexity of relations in the Middle East region. From the four explanations, the formulation of the problem that needs to be analyzed is: "what is the strategy for the concept of Qatar's continuing education as an effort to improve its image as a model of future education?

\section{METHODOLOGY}

The method used in this study is by conducting systematic review that collects information relevant to the problem or phenomenon discussed. Information is obtained from written and electronic sources, i.e. Science Direct, Emerald, and Google Scholar, also ResearchGate; from the beginning, we found 314 articles selected by abstract, 86 articles selected from the background, 44 articles were selected from methodology, 18 articles were selected for results. Writing this essay is expected to provide useful value to readers in order to understand Qatar's sustainable education strategy as a national measure to achieve their goal for future education destinations, and the purpose of this research is to provide readers with an overview of Qatar's strategy in maintaining the social-cultural future aspiration. The scope of this essay writing includes an introduction, discussion and closing with restrictions on Qatar's soft diplomacy strategy as a national defense measure.

\section{RESULTS AND DISCUSSION}

Qatar, in the last 10 years, has transformed into a very rapidly developing country. Qatar's position is in the Middle East/West Asia region, which has a regional condition where there is massive disillusionment with the government regimes for their failure to effectively manage their respective economies and distribute the huge wealth from oil sales. It is therefore not surprising that Qatar remains unaffected by the phenomenon of the "Arab Spring".

In 2017 relations between Qatar and the Gulf countries heated up again in the form of severance of diplomatic relations and an economic embargo, with the official reason being the allegation that Qatar supported hard-liner sects such as the Muslim Brotherhood, ISIS, the Hamas group and other radical sects. The form of Qatar's support for these radical groups is allegedly carried out through financial support in the form of a flow of funds for the purchase of weapons. In addition, Qatar is also considered to be too interfering in the internal affairs of neighboring GCC member countries. The next trigger came from Saudi Arabia's anger at Qatar's leader Sheikh Tamim bin Hamad Al Thani's speech at a military ceremony calling Iran a "great power". Sheikh Tamim bin Hamad Al Thani's speech at the military ceremony was broadcast by Qatari media, namely Qatar News Agency (QNA), which then made Saudi Arabia take action in the form of an anti-Qatar media 
campaign. The Qatari government, represented by the Qatari foreign minister, gave official confirmation that QNA had been hacked by an irresponsible group and spread the news without a clear basis. Qatar rejected the statement and confirmed that at that time, QNA was out of government control. On June 5, 2017, the Gulf countries, namely Saudi Arabia, the United Arab Emirates and Bahrain, severed diplomatic relations and imposed an economic embargo on Qatar by closing trade, land, air and sea routes to Qatar. The closed access has the potential to disrupt Qatar's economy because it is estimated that $40 \%$ of Qatar's total imports come from these routes, especially land routes with Saudi Arabia. This is the background of the conflict related to the severance of diplomatic relations by the Gulf countries against Qatar.

Thanks to its large oil and gas revenues, Qatar continues to invest heavily to deal with the economic embargo imposed by the gulf countries. Therefore, Qatar is taking steps in its defense diplomacy strategy (soft power) through, firstly, increasing education, making the country a world leader in terms of the percentage of GDP spent on education. In addition, literacy rates reach 93 percent, and 88.6 percent of girls are able to read and write, which is the highest percentage in the Arab world. In recent years, Qatar has been aggressively wooing and won the prestigious title (Gonzalez G, Karoly LA, Constant L, Salem H, Goldman CA, 2008). A US university will open a branch in Qatar, where they offer the same degree as the parent university in the US. In the framework of the strategy to attract foreign universities, Qatar has built an education city to centralize all Universities in the same region. Notable universities include Carnegie Mellon University, Georgetown University, Commonwealth University of Virginia, Weill Cornell Medical College, and Texas A\&M University (Kelley \& Dikkers, 2016).

Therein lies the impact of Qatar's long term plan on Middle Easterners and other foreigners who are attracted to these universities in Qatar. Many Middle Eastern students will become elites in their respective countries, and thus the relationships they forge with Qatari citizens and other international students, coupled with their hands-on experience living in Qatar, will make them much more tolerant of Qatari foreigners in the future. In addition, schools in Qatar's educational cities serve as credible alternatives to higher education for Arabs who are hesitant to pursue higher education in the West either due to visa restrictions or cultural considerations (Mogren \& Gericke, 2017). This adds to Qatar's growing prestige in the Middle East and its ability to shape the minds of current and future generations of Middle Eastern and Muslim elites. It is also important to note that most of the faculty members at these universities are Westerners who are ready to shape the hearts and minds of future Arab leaders towards moderation, a Qatari foreign policy goal (Richer, 2014).

It is noteworthy that during the Cold War, the influence of US Soft power in the form of cultural exchange and the thousands of international students who came to study in the US created a significant advantage for the US over its Cold War foes. Some of the pioneering international students from the Soviet Union played an important role in the peaceful defeat of the Soviet Union as they eventually rose to positions of influence after they returned to their respective countries and began to challenge the status quo from within. Second, Diplomacy Image Building through Al Jazeera media becomes a negotiator or mediator for various regional conflicts (Williams J, 2007). Al-Jazeera is part of Qatar's foreign diplomacy tools to spread influence not only in the Gulf region but also throughout the world. Even though the press is not free in this country, this television network has contributed to the democratization known as the Arab Spring, which has shaken up a number of regimes in the Gulf region. Qatar was until recently a relatively unknown country. However, the establishment of the Al Jazeera media empire by the Qatari government in 1996 has given the country unprecedented exposure in the world as Qatar is now synonymous with the famous Al Jazeera brand, which is now universally recognizable. The ability of any country to exert the influence of soft power by promoting its goals or values is highly dependent on its ability to promote the usefulness of the proposed objectives through media that the targeted audience trusts or obtains information from (Madsen, 2013).

Over the years, the US and UK have had great success in promoting their agendas around the world through their dominance over major media sources such as CNN, BBC, and Voice of America. 
However, the duopoly of American and British Media dominance has been broken by Al Jazeera since its founding in 1996 and remains a force in influencing attitudes and thoughts of people in the Middle East. In this decade, the "information war" has received recognition from Western leaders as the influence of Al Jazeera's soft power, which is very strong. Al Jazeera has been a leader who has truly changed people's minds and the way they behave. And like it or not, it's so effective; in fact, Al Jazeera's views are increasing in the United States because it's real news. The world may disagree with that, but we feel like we get real news all the time (Michelsen \& Fischer, 2017).

Based on the description of several steps of Qatar's diplomacy strategy above and analysis has been carried out using relevant theories and concepts, it can be seen that the implementation of Qatar's soft diplomacy is always intended as an effort to defend the country from various threats, both open war and indirect war, such as an economic embargo. Then to further analyze this phenomenon, an analysis can be done using the SWOT analysis technique. In the phenomenon that the author raises, there are internal and external factors regarding the implementation of soft diplomacy. Qatar has strengths, namely established financial support; and a large military operation in the Middle East which is a strength and facilitates the implementation of soft diplomacy by Qatar, but this facility has weaknesses/weaknesses, where the potential of human resources/personnel is limited; Qatar/UAE situation tends to be stable; Peacekeeping Force will reduce the number of troops in the country. There is also an opportunity, namely with the Role of Mass Media (Al-Jazeerah); "Carrot" soft power operation; Opportunity to exchange intelligence data. Then there is the threat, Qatar is experiencing a food crisis because it is very dependent on Saudi Arabia as Qatar's food supplier. So, from the SWOT analysis, it produces an effective strategy in dealing with existing problems, namely by using the W-O strategy; the strategy is to utilize attractiveness and "Carrot" diplomacy in carrying out its soft power in the Middle East region to get a good positive image; host multilateral conferences; increasing the role of the media in Qatar's public diplomacy. Qatar uses its enormous wealth of natural resources as a tool for its foreign policy to build its regional and international profile. However, Qatar does not have the organic influence that other countries have over others, such as the influence of Saudi religion, the influence of American democracy and the influence of the Chinese economy. As a result, Qatar is increasingly relying on its financial strength when mediating conflicts by promising large sums of money after a peace settlement to build infrastructure and so on. This model of diplomacy is known as "Carrot Diplomacy". For war-torn and cash-strapped countries, Qatar's bid for "Carrot" as a form of peace is a lofty goal.

Despite the severance of diplomatic relations, which resulted in the deterioration of Qatar's economic condition, it prompted Qatar to seek solutions in overcoming the crisis by making new policies, namely by building the country as a place of business for companies wishing to trade with Kuwait, Iran, Iraq, Pakistan and Oman. One of the new policies made by Qatar is in terms of food. The first policy, in terms of food security, has become a concern for the import-dependent country of Qatar. This issue has become important since the dispute with the Gulf states began, and the state of Qatar lost some of its main food imports. To overcome this, Qatar made a policy to support the local economic sector in establishing and developing a presence of local products in the market, creating new opportunities for cooperation and business.

As such, Qatar has achieved a respectable regional and international reputation disproportionate to its small size and limited military capabilities, all through a deliberate policy in which it uses its tremendous resources as carrots and sticks. As part of its public diplomacy strategy, Qatar pursues a type of deliberate diplomacy that has been described as "Niche Diplomacy", "defined as targeting "resources in specific areas capable of generating valuable gains." In line with this strategy, Qatar has been scrambling for resources in six areas in the hope of using soft power leverage to resolve some of the Middle East's most vexing conflicts. Furthermore, observing Qatar's conflict with the Gulf countries, which resulted in the severance of diplomatic relations and imposing an economic blockade on Qatar that continues, in 2017 Saudi Arabia and its allies submitted 13 demands that must be fulfilled by Qatar, but the diplomatic efforts shown by 
Saudi Arabia were not responded to by Qatar. who think the demands are unfounded and are a Saudi way to violate Qatar's sovereignty (James, 2009).

Saudi Arabia is an influential country in the Gulf region and, of course, always tries so that its influence can always be peaceful in other small countries. If we look at the factors described by Alexander L. George (2012) that affect the success or failure of a country's diplomacy, it can be seen that the purpose of the Saudi ultimatum can be considered reasonable because in order for unity to occur in dealing with an issue, in this case facing the issue of terrorism and extremism. However, a country certainly cannot impose its will if there are differences in the way the country views a problem. Saudi Arabia and its allies imposed a land, sea and air blockade as a result of Qatar refusing to comply with the given conditions. In the author's view, if Qatar complies with Saudi requests, it is not impossible that in the future, Qatar will always be the shadow of Saudi Arabia. Therefore, Qatar refuses to comply in order to assert the sovereignty of their country. Qatar's foreign minister also stated that the demands were intended to violate Qatar's sovereignty, deny freedom of speech, impose audits, and implement oversight mechanisms against Qatar. However, in addressing the Qatar conflict and the Middle East diplomatic crisis, the solution offered by the author as a diplomatic effort with a compromise method through superpower countries such as the United States, Russia and China or an international organization, the United Nations (UN), has strong potential to become an effective mediator in diplomatic tensions, so it is hoped that these countries will be more neutral in responding to the Middle East political tensions (Augustine \& Krop, 2008).

\section{CONCLUSION}

On June 5, 2017, several Gulf countries, including Saudi Arabia, United Arab Emirates and Bahrain, cut diplomatic relations and imposed an embargo or economic blockade on Qatar by closing trade, land, air and sea routes to Qatar. The economic embargo on Qatar has an impact, especially in the economic sector, namely the disruption of the distribution of energy from Qatar, having an impact on imports, flights and Qatari stocks as well as having an impact on human rights. Defense diplomacy strategy using a soft power approach, Qatar using the mass media is still very influential even today and plays a big role in shaping the opinions of its listeners, which is called the Image Building Diplomacy strategy through Al Jazeera media and using soft power diplomacy through education. The strategic step in dealing with the economic embargo is to build the country as a place of business for companies wishing to trade with Kuwait, Iran, Iraq, Pakistan and Oman. Where to support the local economic sector in building and developing the presence of local products in the market creates new opportunities for collaboration and business.

From the next discussion, it is hoped that lessons can be drawn for Indonesia to see how Qatar takes strategic steps to defend the country from various threats that come. The strategy that has been carried out by Qatar to get out of the impact of the embargo, Qatar has proven successful where until now, Qatar has not met any demands from Saudi Arabia, and Qatar is still able to maintain its country's economy through several new collaborations.

At the end of writing this essay, the author can convey several suggestions, namely: first, this essay can be used as a reference in reviewing education as the new approach to enhance national strategy/agenda, especially in economic uncertainty; and second, to all readers, it is hoped that this research can be used as a source of reference in reviewing the strategic steps of Qatar's strategy to enhance their ability to attract people and investor all over the world. Thus, this research was made as a form of the author's analysis of the conceptual case study. Through this research, the author realizes that diplomacy and negotiation are important instruments that describe the relationship between one country and another and will determine the final outcome of relations between countries. 


\section{REFERENCE}

8th Edition Cooperation Council for the Arab States of the Gulf (GCC).The Process and Achievement. Riyadh: InfoRmation Affairs Sector of Secretariat General, 2014, 33-38

Augustine CH, Krop C. Aligning Post-Secondary Educational Choices to Societal Needs: A New Scholarship System for Qatar. Santa Monica, CA: RAND Corporation; 2008.

Bajaj, M., \& Chiu, B. (2009). Education for Sustainable Development as Peace Education. Peace \& Change, 34(4), 441-455. DOI: 10.1111/j.1468-0130.2009.00593.x.

García-González, E., Jiménez-Fontana, R., \& Azcárate, P. (2020). Education for Sustainability and the Sustainable Development Goals: Pre-Service Teachers' Perceptions and Knowledge. Sustainability, 12(18), 7741.doi:10.3390/su12187741

Global FinanceMagazine, Qatar Investment Authority in Europe https://www.gfmag.com/magazine/january- 2015/Qatar-investment-authority-alThani headsovereign-wealth-fund

Gonzalez G, Karoly LA, Constant L, Salem H, Goldman CA. Facing Human Capital Challenges of the 21st Century: Education and Labor Market Initiatives in Lebanon, Oman, Qatar and the United Arab Emirates. Santa Monica, CA: Rand Corporation; 2008.

James, H. The Creation and Destruction of Value: The Globalization Cycle. Cambridge, MA: Harvard University Press, 2009.

Kelley, C. and Dikkers, S. (2016), "Framing Feedback for School Improvement Around DistributedLeadership", Educational Administration Quarterly, Vol. 52 No. 3, pp. 392-422.

Madsen, K.D. (2013), "Unfolding education for sustainable development as didactic thinking and practice”, Sustainability, Vol. 5 No. 9, pp. 3771-3782.

Michelsen, Gerd \& Fischer, Daniel. (2017). Sustainability and Education. Sustainable Development Policy: A European Perspective (pp.135-158) Chapter: 7Publisher: Routledge.

Mogren, A. and Gericke, N. (2017a), "ESD Implementation at the School Organisation Level, Part 1Investigating the Quality Criteria Guiding School Leaders' Work at Recognized ESD Schools", Environmental Education Research, Vol. 23 No. 7, pp. 972-992.

Mogren, A. and Gericke, N. (2017b), "ESD Implementation at the School Organisation Level, Part 2Investigating the Transformative Perspective in School Leaders' Quality Strategies at ESD Schools", Environmental Education Research, Vol. 23 No. 7, pp. 993-1014.

Mohanty, A. and Dash, D. (2018), "Education for sustainable development: A conceptual model of sustainable education for India", International Journal of Development and Sustainability, Vol. 7 No. 9, pp. 2242-2255.

National Development Strategy 2011-2016. Qatar General Secretariat for Development Planning. 2011. http://www. gsdp.gov.qa/gsdp_vision/docs/NDS_EN.pdf. Accessed April 9, 2014.

OPEC Annual Statistical Bulletin 2017, accessed from: https://www.opec.org/opec_web/static_files_project/media/downloads/publications/ ASB2017_13062017.pdf

Planning Council. Human Development Report for the State of Qatar. The Planning Council General Secretariat. 2007.

PlanningCouncil.TurningQatarintoaCompetitiveKnowledgeBasedEconomy:KnowledgeEconomyAs sessmentof Qatar. 2007.

Qatar's Third National Human Development Report. 2012. http://www.gsdp.gov.qa/www1_docs/hdr3_en.pdf. Accessed October 10, 2014. 
Ramthall, A. and K. Schulze. "Political Reform in the Gulf: The Case of Qatar". Middle Eastern Studies 36 , no. 4 (2000): 47-6.)

Richer, Renee. (2014). Sustainable development in Qatar: Challenges and opportunities. Science Connect. 2014. 22.10.5339/connect.2014.22.

Scherp, H. (2013a), Lärandebaserad skolutveckling. Lärglädjens förutsättningar, förverkligande och resultat [Learning Based School Development. The Joy of Learning, Conditions, Implementation and Results], Lund, Student litteratur.

The World Factbook Central Intelligence Agency accessed from: https://www.cia.gov/librarY/publications/the-world-factbook/geos/qa.html

Williams J. Al Jazeera's booming voice: Developing Qatar's comparative advantage in the middle east. JMEG. 2007;2(4):31 - 46. 